\title{
ENVIRONMENTAL MANAGEMENT IN SLOVENIAN TOURIST ENTERPRISES
}

\author{
I. JURINČIČ ${ }^{1} \&$ Š. BOJNEC 2 \\ ${ }^{1}$ Turistica - Faculty of Tourism Studies Portorož, University of Primorska, Slovenia. \\ ${ }^{2}$ Faculty of Management Koper, University of Primorska, Slovenia.
}

\begin{abstract}
The attitudes towards the natural environment and its uses are becoming an issue of global concern. Climate change and the associated natural disasters have created a demand for different practices in the use of natural and environmental goods in a more long-term, sustainable way to reduce the damage caused by different economic and human activities. Such activities also include leisure and tourist activities where the focus should be on sustainable tourism development to strike a balance between economic interests and ecological requirements. The EU has adopted and implemented programmes for sustainable development where special support is devoted to the sustainable economic development of different economic activities. Considering the level of economic development and Slovenia's membership in the EU since 2004, it is surprising that in the field of tourism there is only one certified enterprise or product with the EU Eco-label in Slovenia. This is even more striking if we consider the fact that ecological policies have already been implemented at the government level for few years and that based on the rate of biodiversity Slovenia is among the richest regions of the EU (Natura 2000). There are specific ecological programmes to protect the environment, but few in the field of tourism in comparison to some other EU countries. So far, there is only one registered tourist enterprise 'Spa Snovik' near Kamnik in Slovenia that is certified with the Eco-label. Moreover, 'Spa Radenci' and 'Spa Snovik' are the only tourist suppliers with the ISO 14001 certificate for the integrated management of the environment. In this study, we aim to explain why Slovenian tourist suppliers are reluctant to introduce standards with eco-labels and other ecological symbols. We analyse the costs and benefits of environmental management in tourist enterprises by considering the importance of brand name and image building, which are important for competitive position in tourist markets.
\end{abstract}

Keywords: cost-benefit, climate change, Eco-label, image building, ISO 14001, Natura 2000, sustainable tourism.

\section{INTRODUCTION}

Nowadays contemporary tourists expect and demand high-quality natural environments in the places that provide holidays and leisure activities. We focus on Slovenia, which is endowed with rich natural conditions suitable for environmental tourism, as almost $60 \%$ of its landscape is covered by forests and the country is situated on the Adriatic coast. In addition to 'green' natural forest conditions, there is a part of the Alps with lakes that serves as an excellent place of high-quality natural environment for holidays and leisure activities. The high-quality natural environment has been appreciated during visits particularly by tourists from Germany, Italy and Austria, but more recently the region has attracted tourists from all over the world. It is well known that many German tourists appreciate high-quality natural environments as a significant factor of destination competitiveness and demand of tourists for holidays. For example, to the question 'When are you thinking about your next holidays, which natural environmental factors are the most important for your decisions?', the most frequent responses from German tourists were clean beaches and clean water, no dust in and around tourist places and non-urbanized countryside. Slovenia is a tourist destination that complies with such tourist expectations, as it is one of the EU countries with the greatest degree of biological diversity. A growing number of tourists are demanding 'green' and fresh, high-quality natural environments, which is determined by the increase in tourist incomes and the hotter weather conditions with increasing temperatures that are caused by climatic changes and global warming. This is a challenge for tourist enterprises that to a large extent understand the importance of the eco-standards and eco-labelling.

(C) 2009 WIT Press, www.witpress.com

ISSN: 1743-7601 (paper format), ISSN: 1743-761X (online), http://journals.witpress.com

DOI: 10.2495/SDP-V4-N3-226-237 
As can be seen from Table 1, which lists some of the most important demands of German tourists in the world tourist markets, around half of the German tourists want to spend their holidays and free-time leisure activities in well-maintained natural environments [1]. Such tourist expectations and demands provide the signals for tourist products and offer directions for their adjustment and innovation in the areas of ecological-environmental management and sustainable tourism development. Similar expectations and demands are also present among tourists from other EU countries such as Austria, Great Britain and France.

In Europe, more than 50 ecological brand names and certificates have been developed in the field of tourism to provide tourist products in accordance with the agreed criteria in different countries. Eco-labelling and the development of eco-certificates assure environmentally friendly tourist facilities that meet the ecological demands of tourists in hotels, camps, beaches, marinas, naturally protected areas, restaurants, golf courses, tourist agencies and other tourist activities [2]. It is worth mentioning a few of the well-known examples of good practices that have successfully operated and implemented these ecological aspects in tourism over the years (Fig. 1): Bio-hotels in Austria, Germany, Italy, Switzerland, Ireland, Spain and France; Ibex-label in Switzerland; Eco-label in Luxembourg; Distintiu de garantía de qualitat ambiental in Spain [3]; Nordic Swan and Green Key in Scandinavia; Green Tourism Business Scheme in Great Britain; Milieubarometer in the Netherlands; Clefts Vertes in France; Legambiente Turismo in Italy and European Blue flag and Green Globe 21 [4]. In 2004, the EU's scheme of eco-labelling, called 'Eco-label', for tourist accommodations was set up. This eco-symbol has become recognizable with already known logos for environmentally friendly industrial products such as Green Daisy. It has also been adopted by Slovenia, which prior to its entry into the EU did not develop its own scheme of eco-certificates.

The use of eco-symbols in the EU has confirmed that most of the certified tourist enterprises have succeeded in reducing the quantity of wastes and the use of water, energy and detergents. These tourist enterprises also cooperate significantly with local communities to resolve traffic problems and maintain the environment. Several tourist enterprises have decided to obtain eco-certificates and so they have invested in its promotion with the expectation that they will reduce costs, gain more visitors and in the long run increase their revenues. However, there is no uniform view on the concept of sustainable tourism development due to specific practices in different environments where tourism is developed and operates. Different definitions for sustainable tourism development exist in literature [5]. On the basis of the most frequently quoted components of sustainable tourism development in literature,

Table 1: Expectations of German tourists in the places of holidays and leisure activities with respect to factors of the environment [1].

\begin{tabular}{lc}
\hline Factors of the environment & Share in $\%$ \\
\hline Clean beaches and water & 64.5 \\
Absence of dust in tourist places and the surroundings & 59.1 \\
Non-urbanized countryside & 50.0 \\
Qualitative protection of nature in the tourist destination & 45.8 \\
Without noise pollution due to traffic and discos & 51.0 \\
Environmentally friendly accommodation facilities & 41.8 \\
Little traffic and arranged public transport in the tourist destination & 35.1 \\
Opportunity for easy access to tourist destination by bus and train & 29.0 \\
Offers of environmentally friendly accommodation facilities in the & 18.7 \\
catalogues of tour operators and travel agencies & \\
\hline
\end{tabular}



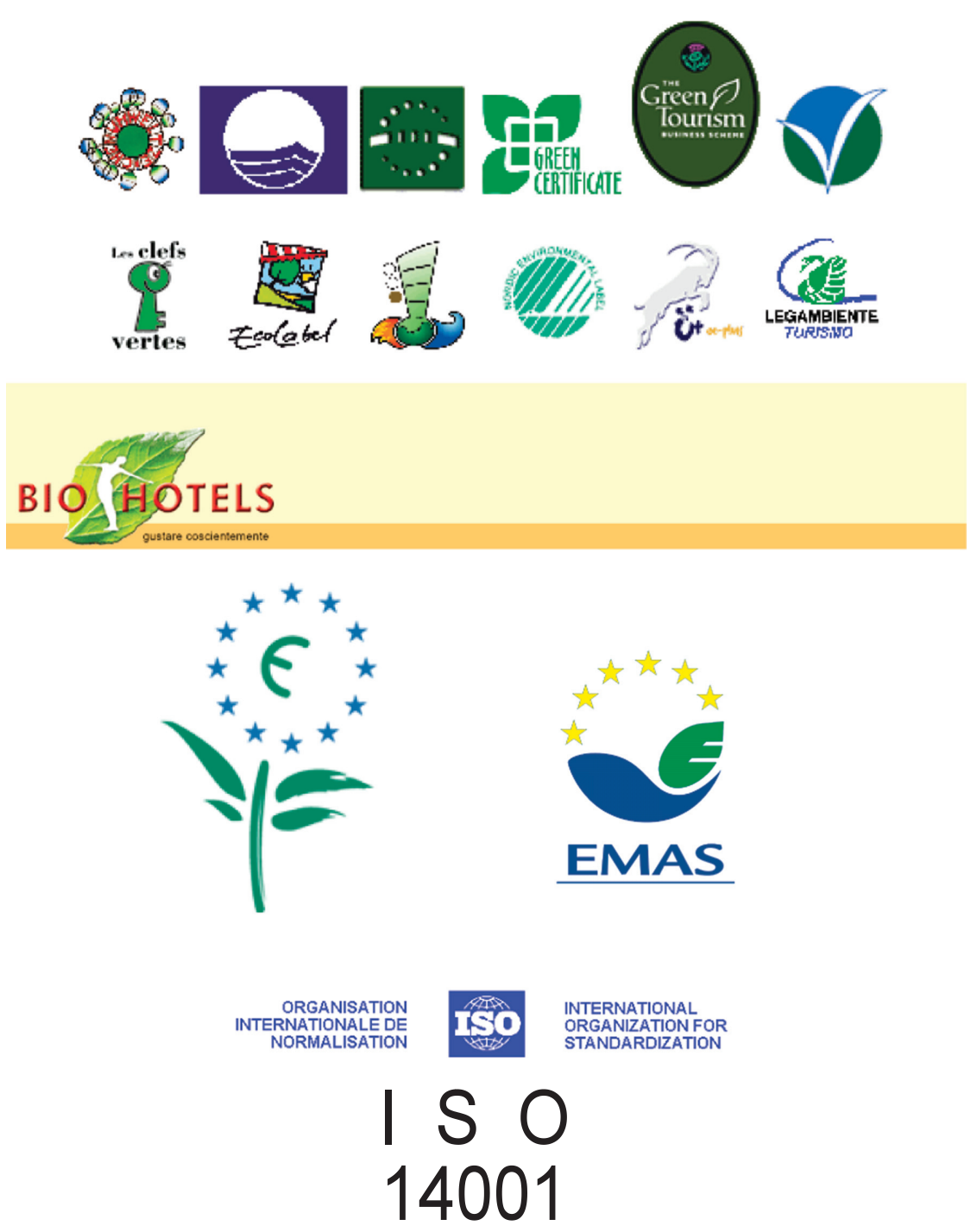

Figure 1: Eco-symbols and eco-certificates in the EU [3, 4].

74 leading experts in the field of tourism from all over the world were offered a list of 16 characteristics to select the five most important among them and to rank them according to their importance on a scale of 1 to 5 [6].

Figure 2 provides the findings on the importance of individual characteristics of sustainable tourism development. The long-term view was confirmed as the most significant feature of sustainable tourism development. In second place was the feature that sustainable tourism development contains wellprepared tourist development programmes, followed by two equally important features - that it provides efficient use of resources and envisages inclusion of local communities. In fourth place was the feature that it preserves the stock of natural resources. These research findings confirmed that some indicators of the sustainable tourism development differ significantly from one territory to another, whereas 


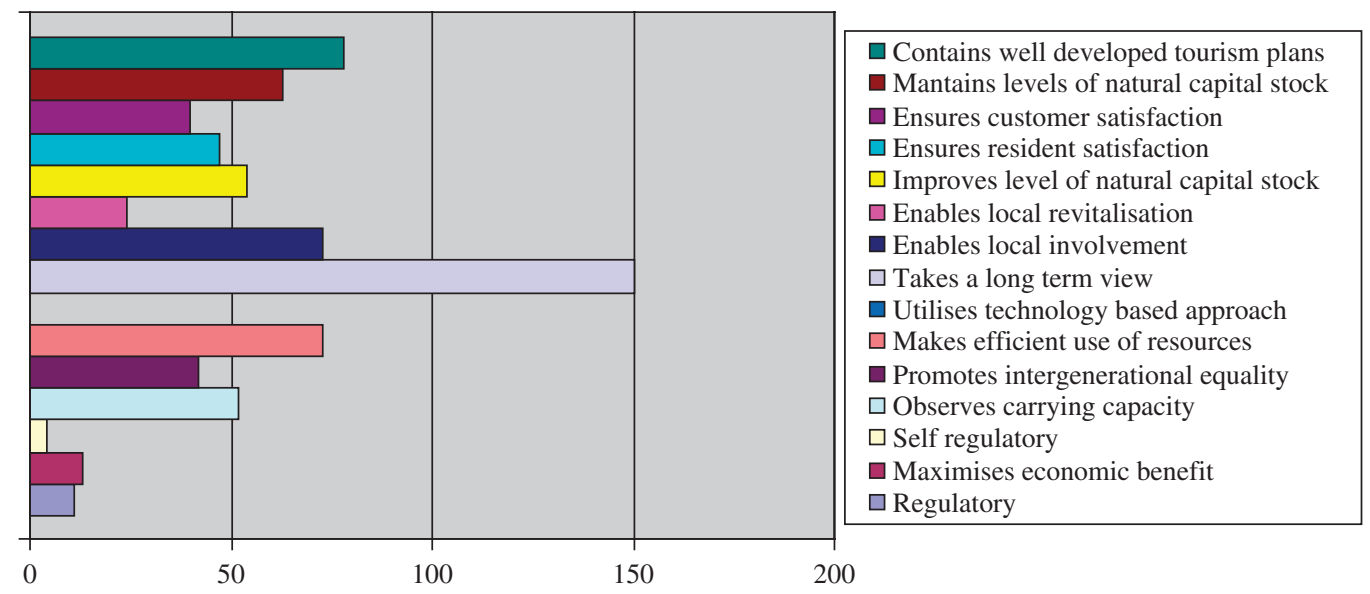

Figure 2: The importance of individual characteristics of sustainable tourism [6].

some other indicators are indeed of a global nature. Due to reasonable programming of tourism development, it is required to establish indicators of sustainable tourism development in different environments and compare them with already available indicators. One of these indicators is monitoring the use of water and energy, which is further investigated in the case of hotels in the Northern Adriatic.

\section{PROTECTED NATURAL AREAS IN SLOVENIA AS PER NATURA 2000}

At present, $11 \%$ of the total Slovenian territory is naturally protected. With the implementation of the Strategy of Territorial Development in Slovenia since July 2004, the naturally protected areas have been estimated at 33\% of its territory, out of which Triglav National Park represents $4.1 \%$ of the Slovenian territory. Moreover, 3 regional parks, 40 landscape parks, 49 natural reserves and 623 natural monuments are protected. However, there are some shortcomings in the implementation of the proposed protected areas, which are due to shortage of qualified labour, lack of finance and appropriate expertise, lack of interest in municipalities and lack of political support as well as reorganization of states at the local governance level and almost inexistent inter-sectoral mutual interest and cooperation.

In April 2004, Slovenia endorsed and thus confirmed the proposal of the Natura 2000 areas, which is currently under investigation by the European Commission. Slovenia has been identified as having the greatest degree of biological diversity in the EU [7]. Two hundred and eighty-six areas have been identified, out of which 260 have been identified on the basis of regulation on habitats (32\% of the Slovenian territory) and 26 on the basis of regulation on birds (23\% of the Slovenian territory) (Figs 3 and 4). Often, there is overlap between these geographical areas because $60 \%$ of the areas proposed on the basis of regulation on habitats are also included within the proposed special protected areas by regulation on birds. Thus, both Natura 2000 areas (on habitats and birds) together covered $36 \%$ of the Slovenian territory. Most of the protected areas are covered by forests, which are also associated with the prevailing landscape in Slovenia. A significant proportion of the protected areas are rocky land areas without vegetation; $9 \%$ of the protected areas are situated above the forestry border and a significant proportion is covered by grassland. Twenty-five percent of the territory is located within the boundaries of the protected areas (in the Triglav National Park, regional and landscape parks as well as in reserve and natural monuments), which is also included in the Natura 2000 areas. 


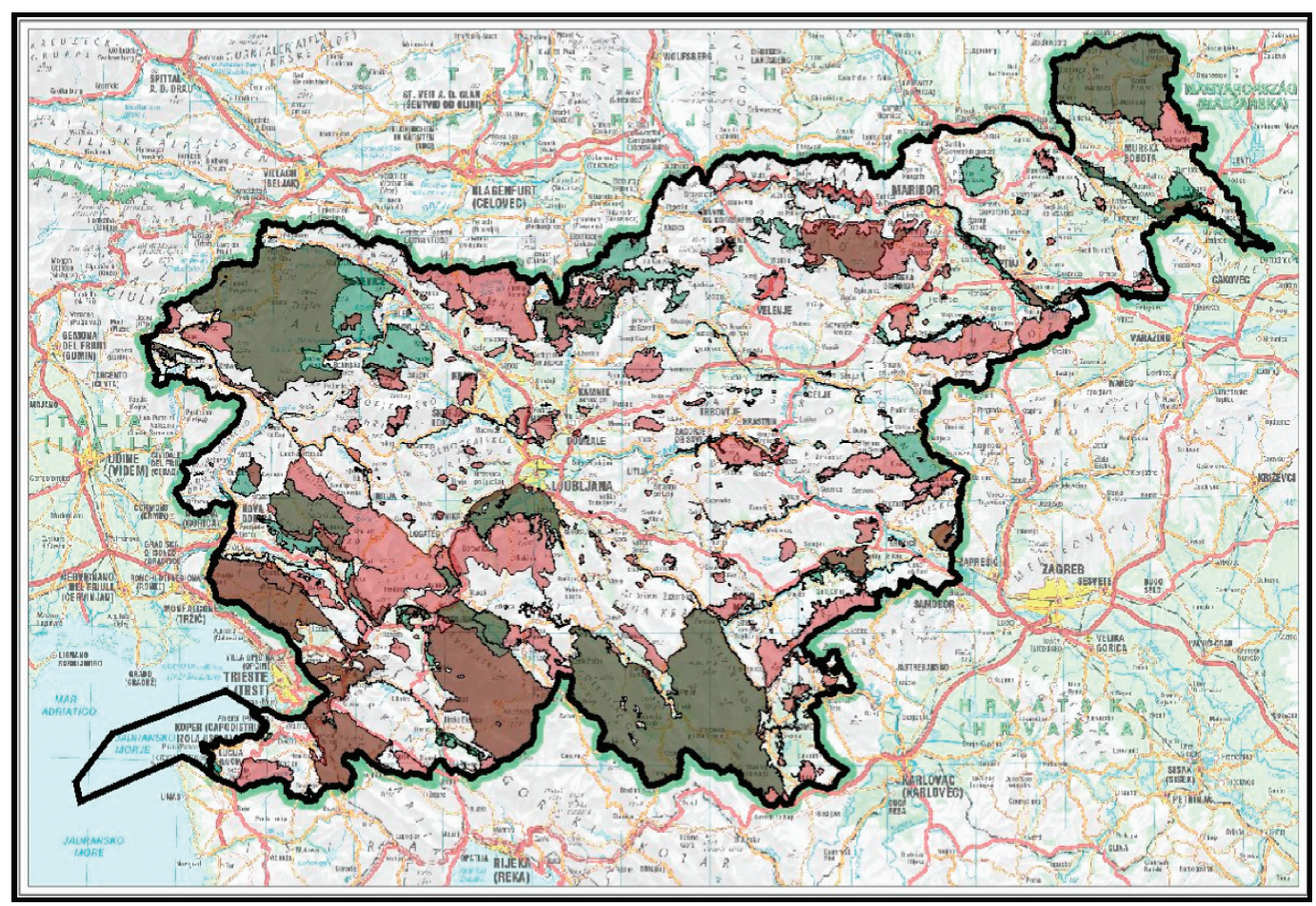

Figure 3: Natura 2000 areas by regulation on habitats and birds in Slovenia [7].

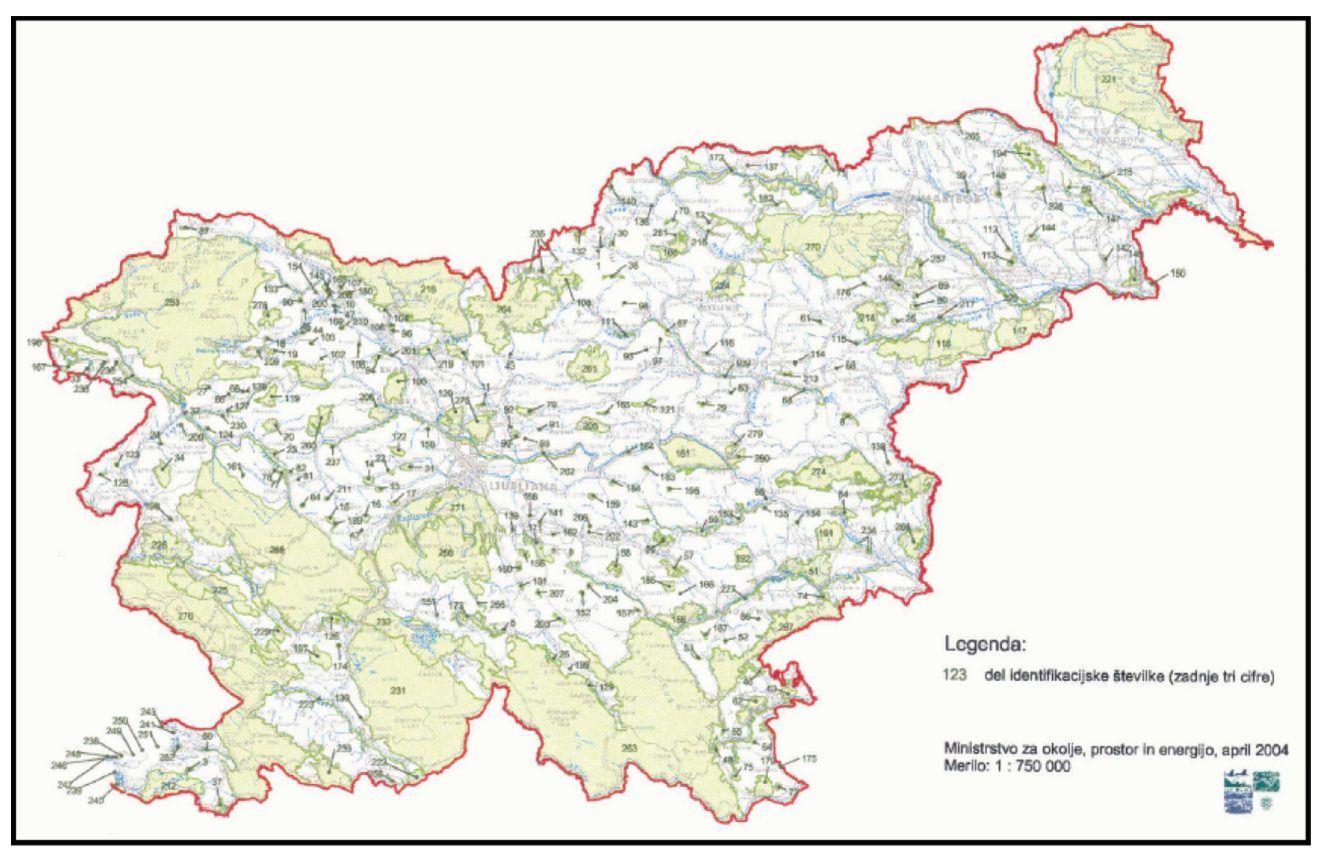

Figure 4: Natura 2000 areas by regulation on birds in Slovenia [7]. 
The preservation of nature, particularly the biotical diversity, is not the task of the natural resources protection sector alone, which does not have enough staff and resources for this purpose. Due to this, the natural resources protection sector needs to be developed further and particularly strengthened for partnerships and cooperation with other participating sectors such as forestry, agriculture, tourism and similar activities, which operate with most of the natural attractions and resources to support biotical diversity, provide advice and monitor the implementation.

However, so far the Slovenian state has not set up a system to provide natural protected areas with a certain implementation comparative advantage in exchange for constraints in their economic development, irrespective of the fact that the natural protected areas provide general environmental benefits. This current situation in implementation of the natural protected areas is associated with the generally accepted normative protection, which is based on a system of forbiddances and restrictions, but in practice do not provide enough real attention, resources and expert support for the proposed natural protected areas. On the other hand, in Slovenia, there are some good experiences in the implementation and monitoring of the natural protected areas in the Triglav National Park, Regional Park of Škocjan's Cave and Natural Parks in Logarska's Valley and Sečovlje's Salt Production Areas, where some comparative advantages based on providing environmental goods are particularly identified as important in tourism development. This is, however, not well known, not visible and not well presented to the broader society, local communities and local economies, which are situated in the territorial areas that are envisaged for environmentally protected areas in Slovenia.

The comparative advantages that arise from the gains of environmental protection on economic development can be achieved only in the long run. The environmental protection of a certain territory can induce socio-economic changes due to the changed and often reduced traditional economic development opportunities in the new naturally protected territories. However, at the same time it provides new development opportunities in activities such as sustainable tourism and environmentally friendly agriculture and forestry development.

Without local citizen's participation, it is difficult to expect implementation of environmental interests in sustainable development in spite of the normatively natural protected areas. The same holds for the protection of natural attractions and natural values outside the natural protected areas. In particular, the implementation practices in the proposed natural protected areas have failed so far because they arrived at the local level with delays and/or unprepared. Even when the decisions and implementation practices on the natural protected areas are the responsibility of the state, there is a necessity to ensure cooperation with local communities and local economies from the very beginning. The great potential and unutilized opportunities in sustainable tourism development are seen from the marketing of the natural protected areas as tourist attractions and local territorial products and services, which are based on the quality of agricultural, food and tourist products and services. These strategies of sustainable tourism development should be supported by the introduction of recognized brand names for local products and services in the territories of the natural parks $[8,9]$.

\section{CLIMATE CHANGE AND ECOLOGICAL MANAGEMENT}

The group of experts for climate change at the United Nations [10] predict that global warming and climatic changes are expected to have significant effects on tourism development. The implications of climate changes on tourism development differ from each region [11]. Therefore, the question is how the climatic changes might affect the evaluation of tourist resources in different tourist regions in Slovenia.

Higher temperature of air and swimming waters as well as an increase in the number of hot days [12] are expected to positively influence tourism development due to: 
- a longer swimming season and greater interest in swimming by tourists in the seaside tourist resorts (in comparison with the current situation, e.g. in Spain and Greece) and in other swimming and spa tourist towns in Slovenia (e.g. Pomurje and Posotelje, among others); and

- availability of better and improved thalassotherapies and climatic spa resorts in Slovenia; due to the expected increase in demands for these services by tourists, an increase in the supply of these services can be expected in the coastal as well as mountainous tourist regions [13].

On the other hand, several factors indicate that at the same time there can be negative impacts of climate changes on tourist regions and tourist development in Slovenia. To mitigate and remove the negative impacts of the climate changes on tourism development, there is a need to provide the following additional resources:

- More energy supply for air conditioning in the coastal and other tourist regions.

- Improve the insulation in tourist housing facilities.

- Making artificial snow, which will be very difficult and costly. A shorter skiing season with 'grey' and 'green' landscapes instead of the expected 'white' snow-covered landscapes in the skiing tourist places is likely to reduce their attractiveness to tourists, making them reluctant to move from their places of residence to skiing places, thus reducing the visits to skiing places and the desire for skiing in general. Examples of this situation have already been seen in some winter seasons in the geographical locations between the capital Ljubljana and the skiing place Krvavec as well as other skiing places in Slovenia. These new developments demand the evolution of new tourist facilities and tourist offers in the existing skiing places.

- Introduction of new measures and improvement of existing measures to save energy use.

- A shift from traditional energy sources towards renewable sources of energy such as solar energy, use of biomass, biogas and geo-thermal energy.

A lower amount of rainfall is expected to have the following implications on tourist resources in Slovenia:

- in the Mediterranean parts of Slovenia and in other parts of Slovenia with water-deficient landscapes, it is expected that there will be a shortage of drinking water and water for irrigation, washing and similar uses;

- during the summer period, one can often expect to see more burnt yellow landscapes for longer periods;

- an increase in the danger from natural fires;

- in the higher mountainous parts of the Julian and Kamnik-Savinjska Alps and particularly in the skiing centres in the lower altitudes of Pohorje and other under-Alps landscapes (Cerkno, Stari Vrh above Škofja Loka and similar places) and on the landscapes of higher karst hills (Kalič, Rog-Čermošnjice and similar places), fewer days when the landscape is covered by snow can be expected.

In the tourist regions with temporary water shortages (e.g. Slovenian Istria and Karst), there is a necessity to set up systems for saving drinking water and recycling of wastewaters. It is possible to find examples of such systems in countries like Germany, where separate reservoirs and water installations have been built for recycling water from purifying plants for irrigation, toilets, public areas and similar uses. With such installations, the new investments in the tourist economy (e.g. Hotel Palace in Portorož, hotels in Bled and hotels in spa tourist destinations in Slovenia) would provide spillover effects of good practices to other tourist providers as well as to the larger civil society and 
niche tourist groups, with an efficient message on the environmental and social responsibility for sustainable development. The inclusion of such environmental measures of sustainable tourism development should be a strategy for the biggest investors in the tourist economy in Slovenia (e.g. Istrabenz Group, Sava Group and some other leading tourist enterprises). To promote such practices, it would be desirable that the examples of good practices of environmental management are presented and published on the websites of these enterprises and through other marketing communication media.

Other extreme weather conditions such as more frequent water floods are likely to cause damage to landscapes (forests, agriculture, etc.), traffic and tourist infrastructures in river valleys. Due to this, it is necessary to avoid such potentially risky areas for the construction of tourist and other associated infrastructure to escape natural disasters or to build them in accordance with the regulations for such risky areas.

The critical resources during the expected climatic changes are the supply of electrical energy and water. This is also true in the field of tourism, where tourist enterprises and tourist regions already experience temporary difficulties in providing sufficient quantities of water and energy. In the field of tourism, there are a few tasks that should be carried out in cooperation with the state, municipalities, enterprises and individuals to avoid potential shortages in the supply of energy and natural resources.

- The state should envisage and prepare a strategy and programme of measures to mitigate risks to tourism due to global climatic changes, envisage the adoption of proper measures, such as tax reductions and financial support for research, and the introduction of innovative measures in tourist enterprises and households, and set up an integrated monitoring of natural resources.

- The municipalities should be able to accept the expected climatic changes with adjusted territorial and other development programmes; with investment support for the use of public passenger traffic and the construction of facilities for sport activities, recreation, cultural life and social events; and by setting up continuous monitoring of the environment, using warming systems and providing information to citizens and enterprises.

- Tourist enterprises should introduce saving measures for more rational use of natural and energy resources, speed up environmental labelling of services and products (Eco-label, etc.), and adopt social and environmental responsibility (adoption of environmental memorandums, integrated advertising, sponsorships and donations) and an integrated system of environmental management (ISO 14001, Eco-Management and Audit Scheme (EMAS), etc.).

- Individuals in recreation and tourist activities should practise environmentally safe use of natural resources and change purchasing habits (purchase of agricultural and food products with traceable geographical origin and choose natural certified services and products from environmentally and socially responsible suppliers/producers); maintain quality of life with healthy ways of nutrition and by practicing more physical activities in nature; educate themselves about nature, by monitoring and reducing the negative influences on the environment (e.g. calculation of own $\mathrm{CO}_{2}$ which is proofed on www.umanotera.org [14]).

\section{EXAMPLES OF INTRODUCTION OF ENVIRONMENTAL MANAGEMENT IN TOURIST ENTERPRISES IN SLOVENIA}

'Spa Snovik' near Kamnik is the only registered tourist enterprise in Slovenia that is certified by the EU Eco-label. In addition, eight beaches and marinas are certified by the Blue Flag eco-symbol, which has been introduced as an ecological and environmental symbol in Slovenia. The use of environmental symbols in the EU countries so far has shown that most of the certified enterprises 
behave in a more environmentally friendly manner, generating reduced quantities of wastes and making more rational uses of water, energy and detergents; thus, the introduction of environmental symbols has reduced the negative impacts on the environment. Such certified enterprises are also engaged in resolving problems related to traffic and environmental protection at the local level. Among the important motivations for such environmentally friendly practices that are related to the implementation of environmental certificates are the reduction of costs of tourist suppliers, the increase in demands by tourists for environmentally friendly products and services and the long-term recognized sustainable tourism development, all of which result in improved economic performance with higher revenues from sales and business activities.

For a couple of years, the Terme Radenci, which is a part of the Pannonia Terme owned by Sava Kranj, was the only hotel enterprise in Slovenia that had obtained the ISO 14001 standard partly for the introduction of an integrated system of environmental management. Recently, Terme (spa) Snovik near Kamnik gained a similar certificate and the EU Eco-label. Enterprises with the ISO 14001 environmental certificate or EMAS as a whole then comply with the criteria for environmental management, which are envisaged for the EU Eco-label.

In 2005, Hotel Zlatorog in Bohinj was the first hotel to be certified and the only bio-hotel in Slovenia. This hotel is located in the suburbs of the Triglav National Park near the Bohinj Lake. It had difficulties in providing biologically produced food of Slovenian origin, so they returned the bio-hotel certificate in 2007. The association of ecological farms of Slovenia has over 1,000 members, but so far they have produced only smaller quantities of diversified products. The long-term and strong cooperation with retailing channels is rather weak and the tourist economy, which according to positive experiences in Austria, could improve the general availability and the economic efficiency of production of ecological products.

The main reason for low degree of introduction of environmental symbols and certificates in Slovenian tourist enterprises is the relatively low understanding of the importance of environmental issues by those in the top management. On one hand, they do not see the advantages and opportunities that are associated with the introduction of environmental management in the business activities of tourist enterprises. On the other hand, they are emphasizing the additional costs that are related to the introduction of environmental management (Table 2). Moreover, there is very little cooperation between the actors that can, through joint activities and mutual partnerships, contribute to improvements and thus move developments in a positive direction. This is true for different state institutions

Table 2: Costs for the eco-symbol Eco-label [15].

\begin{tabular}{|c|c|c|}
\hline Type of costs & Costs (euro) & Discounts \\
\hline $\begin{array}{l}\text { Application fee covers the } \\
\text { costs of processing the } \\
\text { application }\end{array}$ & $300-1,300$ & $\begin{array}{l}25 \% \text { for small- and medium-sized } \\
\text { enterprises (SMEs) and applicants } \\
\text { from developing countries }\end{array}$ \\
\hline $\begin{array}{l}\text { Annual fee for the use of the } \\
\text { label is defined at } 0.15 \% \text { of } \\
\text { annual volume of sales of } \\
\text { the product within the } \\
\text { community }\end{array}$ & $\begin{array}{c}0.15 \% \text { of annual } \\
\text { revenue }(500-25,000)\end{array}$ & $\begin{array}{l}25 \% \text { for SMEs and applicants from } \\
\text { developing countries; } 15 \% \text { for } \\
\text { companies registered under EMAS } \\
\text { or certified under ISO } 14001 \text {; other } \\
\text { reductions possible by contacting } \\
\text { competent body for further details }\end{array}$ \\
\hline
\end{tabular}


and local communities as well as for tourist and tourism-associated economic activities such as agriculture, the food industry and forestry, among others.

Surveys that were conducted in 2002 in the hotels in the Northern Adriatic confirmed relatively weak managerial knowledge on environmental management in terms of the use of electrical energy and water [16]. In some cases, there was no data available for the quantity of use of water (Table 3). The differences in the use of electrical energy and water in the Slovenian tourist enterprises are due to the different tourist facilities offered (swimming pools, different sports facilities, etc.) and their geographical locations (Mediterranean, continental part, the Alps and similar geographical tourist destinations) [17-19]. Due to these reasons, the quantity of water use was removed from the list of criteria for the Eco-label and instead more criteria that provide savings for water and energy use were introduced. The crucial aim is that managers in tourist enterprises should understand the importance of these data on the use of natural and energy resources when making managerial decisions for the rational use of these resources and the long-term reduction of their use per overnight stay or per tourist product. In this way, they can contribute to business cost reductions, whereas the introduction of eco-labels and certificates only improves the image of the enterprise and tourist destination [20].

With a brief, descriptive, cost-benefit analysis, we arrive at the following findings and implications that can provide incentives to managers and owners of tourist enterprises in Slovenia for more intensive introduction of environmental management.

The expected costs of introducing environmental management in tourist enterprises include:

- investments and adaptation, restructuring and new buildings to comply with the requirements for the individual certificate;

- education of employees;

- changes in the ways of managing the environment; and

- advice, management and monitoring of projects.

The expected benefits of introducing environmental management in tourist enterprises include:

- better recognition and image of product and services;

- higher prices of services;

- higher demands by environmentally oriented tourists;

- expressed environmental and social responsibility;

- lower material costs (up to $30 \%$, or about $10 \%$ annually);

- higher education level of employees in the field of ecological management; and

- support from state and EU structural funds for investments.

Table 3: Consumption of electrical energy and water in hotels per overnight stay [16-19].

\begin{tabular}{lcc}
\hline State - region & Electrical energy $(\mathrm{kWh})$ & Water $(\mathrm{l})$ \\
\hline Slovenia - Istria & 8.4 & 347 \\
Slovenia - Julian Alps & 8.4 & 283 \\
Croatia - Istria and Kvarner & 7.5 & 371 \\
Italia - Northern Adriatic & 13.5 & 423 \\
Germany & - & $92-180$ \\
Montenegro & - & $200-350$ \\
Malaysia & - & $100-130$ \\
\hline
\end{tabular}




\section{CONCLUSIONS}

There has been a significant increase in the importance of environmental factors and high-quality natural environments in tourists' demands for holiday and leisure activities. This demand pattern has encouraged tourist enterprises to consider the importance of sustainable tourism development at the micro-business level. In this paper we investigate sustainable tourism development in Slovenia, which is considered as one of the EU countries with the greatest degree of biological diversity. We have identified both advantages and disadvantages that result in constraints and shortcomings, thereby widening the gap between the formal adoption of environmental measures and the difficulties in the implementation of measures for the protection of natural resources. The introduction of ecological and environmental management in Slovenian enterprises is also challenged by the expected climate changes. However, the economic cost-benefit reasons are identified as crucial factors to explain why Slovenian tourist managers are reluctant to introduce environmental management in tourist enterprises and to comply with environmental and ecological standards to obtain the eco-labels and other ecological symbols. Therefore, we have presented rare examples of Slovenian tourist enterprises where environmental and ecological management has been used as a factor of competitiveness in the tourist markets.

The Slovenian Government is aware of the importance of environmental management in the development of Slovenian tourist enterprises. In June 2007, the Ministry of Economy of the Republic of Slovenia announced a public tender for the first time for the co-financing of investments in tourist infrastructure by the introduction of special environmental management bonus criteria for the evaluation of proposed projects from the EU funds. The bonus is applicable only if the enterprise that applied for project co-financing has already introduced environmental management. An additional, not yet utilized opportunity for the fast introduction of environmental management in Slovenian tourism enterprises is the direct financial support from a system of state supports for eco-labels and certificates (Eco-label, Bio-hotel, etc.) as well as for the introduction of an integrated systems of environmental management (e.g. ISO 14001 or EMAS). Spain and Italy are examples of good practices in these areas during the last few years [3,21]. It is also possible to find some positive examples in other welldeveloped tourist destinations around the world. Another additional incentive for Slovenian hotels is the guideline for environmental arrangements and improvements of Slovenian hotels, which was prepared by the Ministry of Economy of the Republic of Slovenia [22].

\section{REFERENCES}

[1] Ecotrans und Forschungsgruppe Urlaub und Reisen, Reisenanalyse 2002, Saarbrücken, 2002 (in German).

[2] Font, X., Environmental certification in tourism and hospitality: progress, process and prospects. Tourism Management, 23, pp. 197-205, 2002. doi:10.1016/S0261-5177(01)00084-X

[3] Ecoproducts and Ecoservices in Catalonia, http://mediambient.gencat.net/eng/empreses (accessed January 10, 2008).

[4] Voluntary Initiative for Sustainability in Tourism, http//www.visit21.net (accessed January 10, 2008).

[5] Jurinčič, I., Carrying Capacity Assessment of the Koprsko Primorje for Tourism, University of Ljubljana, Faculty of Arts, Department of Geography, Ljubljana, 2005 (in Slovene).

[6] Miller, G., The development of indicators for sustainable tourism: results of a Delphy survey of tourist researchers. Tourism Management, 22, pp. 351-362, 2001. doi:10.1016/ S0261-5177(00)00067-4

[7] Natura 2000 in Slovenia, http://www.natura2000.gov.si (accessed January 10, 2008). 
[8] Jurinčič, I. \& Bojnec, Š., Natural park as a brand name: Dragonja's valley in Slovene Istria. Strategic Development of Tourism Industry in the 21st Century: Conference Proceedings, Faculty of Tourism and Hospitality, Ohrid, 2007.

[9] Koutseris, E., Sustainable resources management in the context of agro-environmental EU policies: novel paradigms in Thessaly, Greece. Management of Natural Resources, Sustainable Development and Ecological Hazards, eds C.A. Brebbia, M.C. Conti \& E. Tiezzi, WIT Press: Southampton, pp. 217-227, 2007.

[10] Intergovernmental Panel on Climate Change - IPCC, Climate Change 2007: Summary for Policymakers, http://www.ipcc.ch (accessed January 10, 2008).

[11] Agrawala, S. (ed.), Climate Change in the European Alps: Adapting Winter Tourism and Natural Hazards Management, OECD: Paris, 2007.

[12] Environmental Agency of the Republic of Slovenia, http//www.arso.gov.si (accessed January 10, 2008).

[13] Jurinčič, I., Ogrin, D., Brezovec, T. \& Kribel, Z., Managing the Climate Change Impact on the Slovenian Coast, 2007. Submitted to the Climate and Tourism Exchange Service of the UNWTO, http://www.unwto.org/climate/portal/login.php (accessed July 10, 2008).

[14] The Slovenian Foundation for Sustainable Development, http//www.umanotera.org (accessed January 10, 2008).

[15] EU Eco-label, http://ec.europa.eu/environment/ecolabel/documents/pm_fees_en.htm (accessed January 10, 2008).

[16] Gosar, A. \& Jurinčič, I., Sustainable tourism in the Alpen-Adria region: reality and goals, Dela, 19, pp. 141-151, 2003.

[17] Rous, J., Sustainable Development of the Bohinj Part of the TNP and Possibilities for the Development of Active Tourism, Turistica: Portorož, 2003 (in Slovene).

[18] Brönner, A., Ende, S., Langer, M., Mertel, P. \& Raschke, N., Regional Touristic Masterplan Ulcinj, Supplement 2, Environmental Impact Assessment for the Development of Module No. 2, Deutsche Investitions und Entwicklungsgesellschaft: Cologne, 2003.

[19] Kasim, A. \& Scarlat, C., Business environmental responsibility in the hospitality industry. Management, 2, pp. 5-23, 2007.

[20] Jurinčič, I., Carrying capacity assessment of Slovene Istria for tourism. Sustainable Development and Planning II, eds A. Kungolos, C.A. Brebbia \& E. Beriatos, WIT press: Southampton, pp. 725-733, 2005.

[21] Legambiente Turismo Network, http://www.legambienteturismo.it (accessed January 10, 2008).

[22] Sibila Lebe, S. (ed.), Guideline for Environmental Arrangements and Improvements of Slovenian Hotels, Ministry of Economy of the Republic of Slovenia, Ljubljana, http://www.mg.gov.si (accessed January 10, 2008) (in Slovene). 